\title{
Pigeon Pea (Cajanus Cajan) Seed Meal as a Dietary Protein Source for Tank Reared Nile Tilapia (Oreochromis Niloticus) Fish: A Mini-Review
}

\author{
Millicent Khakhathi Ralinala, Felix Fushai, Joseph Jimu Baloyi and Jabulani Ray Gumbo
}

\begin{abstract}
The review explores the potential of tank rearing of Nile Tilapia (Oreochromis niloticus) fish on pigeon pea (Cajanus cajan $(L))$ seed meal as a dietary protein source. Aquaculture is the fastest growing food production sector in the world. Global consumption of fish has doubled over the past years with the developing world responsible for over $90 \%$ of this growth. Therefore, aquaculture has the potential to dramatically improve rural living standards, food security and can combat poverty through income generation, employment creation and the efficient use of local resources. For commercial production, high quality diets are required to achieve optimal growth. Fish feed accounts for at least $60 \%$ of the total cost of commercial fish production with protein and energy the most critical nutrient supplements to support fish growth. Despite the high crude protein and energy values, tropical legume seeds such as the Pigeon pea (Cajanus Cajan L.) have not been used widely in fish feeds.
\end{abstract} pea

Keywords - local fish feed, aquaculture, rural livelihoods, pigeon

\section{INTRODUCTION}

Aquaculture is the "farming" of aquatic organisms including fish, molluscs, crustaceans and aquatic plants, which involves controlled interventions during the rearing process, to enhance production, such as regular and optimal stocking, feeding, protection from predators and many other necessary management (United Nations Food and Agriculture Organization [1]. Aquaculture has the potential to sustainably supplement capture fisheries and significantly contribute to feeding the world's growing population [2]. It accounts for approximately half of the world's total supply of food fish and is the fastest growing sector of the world food economy [1], currently accounts for more than $30 \%$ of all fish consumed and

Manuscript received October 22, 2020. This work was supported in part by the NRF/DAFF project UID 98686, Cyanobacteria and their cyanotoxins Impact on Inland Aquaculture).

Ms Millicent Khakhathi Ralinala is with Jilin University, China

Dr Felix Fushai is with the Department of Animal Science, University of Venda

Prof Joseph Jimu Baloyi is with the Department of Animal Science, University of Venda

Prof Jabulani Ray Gumbo is with the Department of Hydrology \& Water Resources, University of Venda increasing by more than $10 \%$ per year[3]. Utilization of simple culture technologies and minimal inputs from within traditional small-scale systems have been used for centuries. Most fish farmed in these systems benefit local communities and minimize deleterious environmental impacts. In developing countries, these traditional aquaculture systems are offer many benefits which include food security [2].

Worldwide, fish consumption per capita has increased at an average of $9.9 \mathrm{~kg}$ in 1960; to $19.2 \mathrm{~kg}$ in 2012 and $20.5 \mathrm{~kg}$ in 2018 [1]. In developing countries, fish is considered among key sources of food and income for many communities [4]. A fish portion of $150 \mathrm{~g}$ provide $50-60 \%$ daily required protein of an adult [1], However, consumption is subject to local and seasonal production. Over the previous 30 years, aquaculture has been rising at an annual rate of $8.8 \%$ [5]. The global aquaculture production has increased from $13 \%$ to $42 \%$, with the global wild capture production under threat of overexploitation in certain regions [1]. Increased global aquaculture will likely therefore increasingly significantly complement the global wild capture production [1].

About $89 \%$ of the population of Limpopo Province of South Africa is classified as rural [6]. Agriculture plays a major role in the economic growth and development of the Limpopo Province [7]. The province is one of the richest agricultural regions suited for production of cereals and legumes like pigeon pea, which are main ingredients in livestock, including fish like tilapia (Oreochromis mozambicus).

\section{BIOLOGY OF TILAPIA FISH}

Tilapia belongs to the family Cichlidae, in the order Perciformes. Tilapia originated from Africa and the Middle East, where it has been cultured for years. The first tilapia was farmed in the ancient Egypt over 4000 years ago [8]. Tilapia covers the three main genera: Oreochromis, Sarotherodon, and Tilapia species. However, these genera cover over 70 known species in total [8]. The most farmed fish species in the world is Nile tilapia (Oreochromis niloticus) [9]. Apart from Antarctica, Nile tilapia culture has been practiced throughout the tropical, subtropical and temperate regions [10]. Other commonly farmed species that similarly grow fast are the Israeli tilapia (Oreochromis aureus) and the Mozambique tilapia (Oreochromis mossambicus) [8].

Tilapia can be easily cultured in rural conditions because they are low on the aquatic food chain, feeding on algae and 
plant materials [11]. Among the cultured species, tilapia is in third place in terms of production, after carps and salmon, respectively [11]. In terms of temperature and salinity, tilapia species adapt very well and reproduce very fast in favourable conditions. However, tilapia is naturally mostly found in streams, big lakes, and oceans [12]. The survival of fish in extreme temperatures affects the size and health [11]. Optimal temperature is therefore important to achieve the potential growth of tilapia.

Oreochromis mossambicus has many features that make it a good candidate for aquaculture, which explains its status as the most farmed fish [13]. Relative other species, advantages include wide environmental tolerance, which gives it ability to survive in poor water conditions, grow fast, breed easily with no need for artificial interventions, and feeding on a wide range of feeds such as insect larvae, algae, fish finger lings, worms, plants, and detritus [14]. They are resistant to both environmental and management related stress and to diseases, can withstand high ammonia levels, salinity and extreme temperatures [11].

\section{TILAPIA TANK CULTURE}

When there is insufficient water and land, tank culture is the best alternative to pond and cage culture. Tilapia grow well in tanks at high density subject to maintenance of good water quality through aeration and continuous water exchange, renewing dissolved oxygen and removing wastes [9]. Tank culture advantages include higher stocking density, easy management and effective control of environmental parameters. Feeding and harvesting require minimal time and labour, with easy disease control and more yield per unit of land [15]. Disadvantages are that fish must be fed with a complete diet including supplementary vitamins and minerals given limited access to natural foods. The production cost is significantly increased by the need for artificial aeration and water pumping. Recirculation systems require substantially more attention and are expensive, while high fish density can cause stress and disease breakout [15].

In tank culture, water quality is important. Exchanging water continuously is necessary to maintain optimum water quality. Balanced water exchange is critical to avoid the accumulation of toxic substances from unutilised feed and excretory metabolites [11]. About $20 \%$ of water exchange is required per day and if exceeded this may stress the fish and lead mortality and poor growth [16].

\section{NUTRITIVE VALUE OF SELECTED LOCALLY AVAILABLE FISH FEED}

Previous studies have evaluated the nutritive value of different locally available feeds for tilapia fish [15-18]. Adewulo [17] evaluated sweet potato (Ipomoea batatas) leaf meal as dietary ingredient for Tilapia zilli fingerlings. This study agrees favourably with Soko and Kang'ombe [18] on the development of least cost formulated feed for Tilapia rendalli in tank based grown-out culture system. The plant protein was locally available and low-cost ingredients were used in formulating the fish feed. The local fish feed was fed to Tilapia rendalli in tank based on grow-out culture system and improved their growth which was evident by the good percentage increase in weight and acceptable feed utilization indices.

\section{IMPORTANCE OF GRAIN LEGUMES IN RURAL FARMING SYSTEMS}

Legumes are important crops because of the high protein content (Table 1) and fixation of nitrogen into the soil [19]. Legume seeds are highly priced stock feeds due to the high content of protein [20], amino acids, fibre, minerals, and vitamins [21]. A wide range of grain legumes are used as ingredients for animal feed and human consumption [22]. Commercially important legume species include the Common bean (Phaseseolus vulgaris), Chickpea (Cicer arietinum), Mungbean (Vigna radiata), Jack bean (Canavalia ensiformis), Bambara groundnut (Vigna subterranea), Cowpea (Vigna unguiculata), Common pea (Pisum sativum), Faba bean (Vicia faba), Soyabean (Glycine max).

TABLE I: CRUDE PROTEIN CONTENT (DRY MATTER BASIS) OF COMMON GRAIN LEGUMES.

\begin{tabular}{|c|c|c|}
\hline Species & $\%$ crude protein & reference \\
\hline African yam bean & 25.2 & \multirow[t]{7}{*}[23]{} \\
\hline Bambara groundnut & 19.4 & \\
\hline Jack bean & 18.8 & \\
\hline Lablab & 22.5 & \\
\hline Lima bean & 21.6 & \\
\hline Pigeon pea & 21.6 & \\
\hline Soya bean & 33.5 & \\
\hline Cowpea & 20.9 & \multirow[t]{3}{*}{ [24] } \\
\hline Common pea & 25.5 & \\
\hline Rice bean & 25.0 & \\
\hline
\end{tabular}

\section{ANTI-NUTRITION FACTORS IN LEGUME FEEDS}

The most limiting factor in the use of grain legumes as feed are anti-nutritional factors, which reduce the nutritive value [25]. Anti-nutritional factors affect physiological processes such as digestion, absorption, and respiration [26] sufficiently to affect growth when fed unprocessed and at high dietary levels [27].

Examples of some anti-nutritional factors found in legumes and grains:

- Phytate which reduces the absorption of minerals like iron, zinc, magnesium and calcium, by binding them making them unavailable. In small grains $80 \%$ of phytate is in the aleurone layer [28]. In legume seeds $90 \%$ of phytate is found in protein bodies of the endosperm [29]. It can be reduced through enzyme addition such as phytate [30].

- Protease inhibitor inhibits the digestive enzymes which interfere with protein digestion. They cause pancreatic enlargement and decrease growth [31].

- Tannins are antioxidant polyphenol which impair the digestion of nutrients and reduce the absorption of vitamin B12 and can be eliminated by dehulling, autoclaving or alkali treatment [30]. Tannins reduce feed utilization in animals, reduce palatability and growth rate, bind dietary protein and digestive 
enzymes formulating complexes that are not digestible [31].

- Lectins are protein which interfere with the absorption of nutrients in the intestine and they can be removed by heat treatment or autoclaving [30].

\section{Processing Of Legume GRAINS}

Processes such as soaking, boiling, fermentation, sprouting, wet heating and sun-drying of plant ingredients before feed formulating of diets reduce anti-nutritional factors and improve fish growth together and feed intake [32]. The final quality of a plant protein source depends upon the processing method. Soaking pigeon pea for 6-8 hours reduced lectins by $38-50 \%$, tannins by $13-25 \%$ and protease inhibitors by $28-30 \%$ [32].

\section{NUTRIENT REQUIREMENTS AND DIETS FOR FISH}

The prepared complete diets supply all the ingredients (protein, carbohydrates, fats, vitamins, and minerals) required for the fish growth performance and health status. Most used complete diets contain protein $(18-50 \%)$, lipid $(10-25 \%)$, carbohydrate $(15-20 \%)$, ash $(<8.5 \%)$, phosphorus $(<1.5 \%)$, water $(<10 \%)$, and with certain vitamins and minerals [33]. Complete diet is mainly required for fish reared in high density indoors and in cages because they cannot forage freely on natural feeds [33], because dietary proteins are the most important nutrient component of complete formulated diets [34].

Supplemental diets are prepared to help support the natural feed available in ponds, such as algae, insects and many others. These diets are devoid of vitamins and minerals but contain protein, carbohydrates and lipids and hence there is a need to supplement or fortify [33]. The floating feed is important as this allows the farmer to observe the feeding activity and if possible, increase the fish feed [35]. Another study has focussed on the dietary requirements of tilapia feeds with alternative protein sources. These include fishery and terrestrial animal by-product meals, oilseed meals, aquatic plants, single-cell proteins, legumes and cereal by-products [11].

Generally, protein quality of dietary ingredients is the most important factor affecting fish performance, and protein digestibility is the measure of its availability to fish. Protein quality of dietary protein sources depends on the composition of amino acids and their digestibility. Essential amino acid deficiency leads to poor utilization of the dietary protein and consequently reduces growth and decreases feed efficiency [35]. Dietary ingredients should also supply enough energy to support the fish's vital life processes of nutrient transport, growth and reproduction [32].

Apart from the energy supply, lipids serve to transport fat soluble vitamins. Inclusion in plant-based fish diets is critical to spare dietary protein from metabolism for energy, given twice the energy density of proteins and carbohydrates. Fatty acids of the omega 3 and 6 families are essential for Tilapia [33].

Carbohydrates, including free sugars, starches, and readily fermented fibre [37] are considered energetically efficient and cheapest energy source in fish diets. In addition to conversion to fat, fish transiently store carbohydrate for energy as glycogen, which is mobilized as necessary to satisfy the energy demands [33].
Vitamins are organic compounds that can be classified as water-soluble or fat-soluble. In the fish diet, vitamins are required for growth performance, metabolism, reproduction, good health. Fish cannot synthesize vitamins; they are essential form the diet. Vitamin C (ascorbic acid) is a powerful antioxidant which helps maximize the immune response [37]. Deficiencies result in reduced growth, skeletal deformation, haemorrhages, poor wound healing and many other disorders [37].

Minerals are inorganic elements which consist of macro and micro minerals. The minerals are essential in the diet for the normal functioning of the body. In fish, macro-minerals are required to regulate osmotic balance, cell formation and skeletal formation while micro-minerals are required as components of enzymes and hormone functioning [37]. Fish compensate for dietary mineral's deficiencies by absorption of certain minerals from water through their gills and skin [33].

\section{Productivity And Nutritive Value Of Pigeon PeA}

Pigeon pea is an important grain legume crop grown in Eastern and Southern Africa, Asia and Central America [38]. It is in the Kingdom plantae, Order Fabales, Family Fabaceae, Genus Cajanus and Species C. Cajan [39]. In Africa, subsistence farmers in the semi-arid areas mainly grow it [40] because It is a nutritious legume; a cheap source of protein for many poor households and it is a nitrogen-fixing legume, which has the potential to enrich soil fertility [41].

Pigeon pea is a perennial legume shrub, 1-4 meters tall. Its leaves have long hairs on the outside and pubescent and green above with a silver grayish green. The flowers are yellow with red to reddish-brown lines and a red outside. Pigeon pea seed takes 2-3 weeks to emerge after sowing. The root system is a deep taproot up to 2 meters in depth. These deep roots help improve water infiltration into the soil [42]. In Africa, subsistence farmers mainly grow it in the semi-arid areas due to its drought tolerance [40]. Globally, it is ranked fifth in production among legumes, after common beans, soybean, cowpeas and chickpeas [43]. Okah et al. [44] reported that protein level and carbohydrates of pigeon peas were 18.1 to $31.1 \%$ and ranges from 36 to $66 \%$ respectful.

Pigeon pea grows well on a wide range of well-drained soil types [40] and does not survive waterlogged conditions [45]. Its optimum growth $\mathrm{pH}$ ranges 4.5 to 8.0 [46]. Pigeon pea is the most drought tolerant legume, due to its deep rooting systems [47] and can grow at greater than $35^{\circ} \mathrm{C}$ [45].

Pigeon pea is a good source of protein, rich in amino acids, particularly lysine, methionine and tryptophan, and supplies minerals such as iron, zinc, calcium, potassium and phosphorus [48]. The chemical composition of pigeon pea seed and cow pea are comparable (Table 2).

TABLE II: CHEMICAL COMPOSITION OF PIGEON PEA AND COW PEA

\begin{tabular}{|l|c|c|}
\hline Composition & Pigeon pea seed & Cowpea \\
\hline crude protein \% & 21.0 & 22.77 \\
\hline Ash \% & 3.2 & 3.17 \\
\hline Fat \% & 1.7 & 2.17 \\
\hline crude fibre \% & 2.5 & 4.11 \\
\hline Reference & {$[49]$} & {$[50]$} \\
\hline
\end{tabular}




\section{PIGEON PEA AS FISH FEED}

The protein content $\&$ its amino acid profile, fibre, mineral, and vitamin composition qualify the Pigeon pea to be a candidate dietary ingredient in both animal and human diets. Hammed et al. [51] evaluated effects of partial and total replacement of soybean meal with pigeon pea (Cajanus cajan) in diets for juvenile African Mud catfish (Clarias gariepinus). The diets were acceptable with growth \& feed efficacy of $25 \%$ and $100 \%$ inclusion of pigeon pea resulted in $23.34 \mathrm{~g}$ and $25.47 \mathrm{~g}$ average weight gain. On food conversion, 0 and $100 \%$ inclusion of pigeon pea gave the highest food conversion. Alegbeleye et al. [52] evaluated growth performance and nutrient utilization of African Mud Catfish (Clarias gariepinus) fingerlings fed different levels of fermented pigeon peas (Cajanus cajan) meal. Inclusion of $100 \%$ fermented pigeon pea meal did not affect growth performance or nutrient utilization. Ganzon-Naret [53] similarly sustained performance and carcass composition on graded dietary levels of cooked pigeon peas seed meal in diets for Asian sea bass (Lates calcarifer). Feeding soaked pigeon peas at $45 \%$ dietary inclusion to Nile tilapia (Oreochromis niloticus L) fingerlings maintained optimum growth performance and feed utilization in comparison with a commercial fish feed according to Ndau and Madalla [54].

\section{CONCLUSION}

Fish feed accounts for at least $60 \%$ of the total cost of commercial fish production. Protein and energy are the most critical supplements to support fish growth. The scarcity of quality fish feed ingredients is a major constraint to the survival of aquaculture. Local fish feed production is therefore crucial to sustain and develop aquaculture. Agriculture plays an important role in reducing poverty in rural areas and providing a living for more people than any other industry and to quality and affordable fish feed such as pigeon peas would improve fish farming. As fish farming would increase, there will be an improvement in access to animal protein by the population. However, the nutrition and health of the people will also be improved.

\section{ACKNOWLEDGMENT}

We acknowledge National research foundation (NRF), NRF/DAFF project UID 98686, 'Cyanobacteria and their cyanotoxins Impact on Inland Aquaculture' for funding this project and conference participation

\section{REFERENCES}

[1] FAO. The State of World Fisheries and Aquaculture 2020. Sustainability in action, 2020. Rome. https://doi.org/10.4060/ca9229en (date accessed 18.10.2020)

[2] White K, O'Neill B, Tzankova Z. At a crossroads: will aquaculture fulfill the promise of the blue revolution. Silver Spring Meriland SeaWeb: http://www. seaweb. org/resources/documents/reports_crossroads. pdf. 2004.

[3] FAO. The State of World Fisheries and Aquaculture, Rome, Italy: Food and Agriculture Organism of the United Nations.2002

[4] Gabriel UU, Akinrotimi OA, Bekibele DO, Onunkwo DN, Anyanwu PE. Locally produced fish feed: potentials for aquaculture development in subsaharan Africa. African Journal of Agricultural Research. 2007 Jul 31;2(7):287-95.
[5] Toufique KA, Belton B. Is aquaculture pro-poor? Empirical evidence of impacts on fish consumption in Bangladesh. World Development. 2014 Dec 1;64:609-20. https://doi.org/10.1016/j.worlddev.2014.06.035

[6] Oni, S. A., Executive Summary of Agriculltural Industry of Limpopo Provice. In: E. Nesamvuni, S. A. Oni, J. J. Odhiambo and N. D. Nthakheni, eds. Agriculture as the conerstone of the economy of the Limpopo Province of South Africa. South Africa: University of Venda Science and Technology, Thohoyandou.2003.

[7] Mmarete, C. K., Climate and water resource in Limpopo province. In: E. Nesamvuni, S. A. Oni, J. J. Odhiambo and N. D. Nthakheni, eds. Agriculture: a coner stone of the ecomomy of the Limpopo province. Limpopo: Department of Agriculture, Polokwane. 2003.

[8] Webster CD, Lim C, editors. Tilapia: biology, culture, and nutrition. New York, Haworth Press ; 2006 Aug 21.

[9] Rakocy, J. E., Cultured Aquatic Species Information Programme: Oreochromis niloticus, Rome: FAO Fisheries and Aquaculture Department.2005.

[10] Santiago CB, Laron MA. Growth and fry production of Nile tilapia, Oreochromis niloticus (L.), on different feeding schedules. Aquaculture research. $2002 \mathrm{Feb} ; 33(2): 129-36$.

https://doi.org/10.1046/j.1365-2109.2002.00664.x

[11] El-Sayed AF. Tilapia culture. Oxfordshire, London: CABI Publisher. 2019 Oct 16.

[12] Chapman, D.,. IUCN/SSC Invasive Spacies Specialist Group (ISSG): Oreochromis spp. 2006 www.issg.org/database/sppecies/ecology.asp?si=813\&fr=1\&sts=sss.\&la ng=EN [Accessed 24 April 2016].

[13] Chirwa BB. Feasibility study of proposed fish farming scheme at Nyoka village in Mchinji District-Malawi. Ministry of Agriculture and Food Security. National Aquaculture Centre. Domasi, Malawi. 2008.

[14] Nandlal S, Pickering T. Tilapia fish farming in Pacific Island countries. Tilapia hatchery operation. Noumea, New Caledonia: Secretariat of the Pacific Community. 2004;10(2):190-203.

[15] DeLong DP, Losordo T, Rakocy J. Tank culture of tilapia Houston: Southen Regional Aquaculture Centre Publication..2009.

[16] El-Sayed AF, Kawanna M, Mudar M. Effects of water flow rates on growth and survival of Nile tilapia fry. World aquaculture. 2005. 36(1), pp. 5-6

[17] Adewolu MA. Potentials of sweet potato (Ipomoea batatas) leaf meal as dietary ingredient for Tilapia zilli fingerlings. Pakistan Journal of Nutrition. 2008;7(3):444-9.

https://doi.org/10.3923/pjn.2008.444.449

[18] Soko, T., Kang'ombe, J., Singini, W., Matiya, G., Kaunda, E., Kasulo, V., Kefi, A.S., Kassam, D., Longwe, P., Tembo, Y \& Mtethiwa, A. H. N. Development of least cost formulated feed for Tilapia rendalli in tank based grow-out culture system. In Second RUFORUM Biennial Meeting 20-24 September, Entebbe, Uganda. 2010.

[19] Arab EA, Helmy IM, Bareh GF. Nutritional evaluation and functional properties of chickpea (Cicer arietinum L.) flour and the improvement of spaghetti produced from its. Journal of American Science. 2010;6(10):1055-72.

[20] Ogunji, J. O., Uwadiegwu, N., Osuigwe, D. I., \& Wirth, M. Effects of different processing methods of pigeon pea (Cajanus cajan) on the haematology of African catfish (Clarias gariepinus) larvae. In Conference on International Agricultural Research for Development, Deutscher Tropentag, October. 2005 (p. 11-13).

[21] Mitchell, D. C., Lawrence, F. R., Hartman, T. J., \& Curran, J. M. Consumption of dry beans, peas, and lentils could improve diet quality in the US population. Journal of the American dietetic association, 2009.109(5), 909-913.

https://doi.org/10.1016/j.jada.2009.02.029

[22] Singh, R. J., Chung, G. H., \& Nelson, R. L. Landmark research in legumes. Genome, 2007,50(6), 525-537. https://doi.org/10.1139/G07-037

[23] Ajayi, F. T., Akande, S. R., Odejide, J. O., \& Idowu, B. Nutritive evaluation of some tropical under-utilized grain legume seeds for ruminant's nutrition. Journal of American Science, 2010, 6(7), 1-7.

[24] Sharma, B. K., Das, A. and Bujarbaruah, K. M.. Undderutilized life support crop species: production and research in North Eastern Hill Region of India. Umiam Meghalaya ed. India: ICAR Research Complex for NEH Region. 2003

[25] Matić, R., Nagel, S., Robertson, S., Young, I., Mihailović, V., Mikić, A., \& Kirby, G. Vetch (Vicia spp) expansion and use in Australia. Biotechnology in Animal Husbandry, 2005,21(5-6-2), 203-207. 
https://doi.org/10.2298/BAH0502203M

[26] Murray, H. M., Lall, S. P., Rajaselvam, R., Boutilier, L. A., Blanchard, B., Flight, R. M., Colombo, S., Mohindra, V \& Douglas, S. E. A nutrigenomic analysis of intestinal response to partial soybean meal replacement in diets for juvenile Atlantic halibut, Hippoglossus hippoglossus, L. Aquaculture, 2010,298(3-4), 282-293.

https://doi.org/10.1016/j.aquaculture.2009.11.001

[27] Oresegun, A., \& Alegbeleye, W. O. Growth response and nutrient utilization of tilapia Oreochromis niloticus fed varying dietary levels of cassava peels based on rations supplemented with di-methionine Fish Nutrition and Fish Feed Technology in Nigeria. In Proceedings of the first National Symposium on Fish Nutrition and Fish Feed Technology Lagos NIOMR (pp. 8-13). 2001

[28] Raboy, V. myo-Inositol-1, 2, 3, 4, 5, 6-hexakisphosphate. Phytochemistry, 2003,64(6), 1033-1043. https://doi.org/10.1016/S0031-9422(03)00446-1

[29] Harland, B. F. Nutrition. In: G. A. Spiller, ed. CRC Handbook Dietary Fibre in Human Nutrition. Bacon Roton: CRC Press, pp. 674-680. 2001

[30] Vikas, K., Debtanu, B., Kundan, K., Vikash, K., Mandal, S. C., \& Clercq, E. D. Anti-nutritional factors in plant feedstuffs used in aquafeeds. World aquaculture, 2012,43(3), 64-68

[31] Emire, S. A., Jha, Y. K., \& Mekam, F. Role of anti-nutritional factors in food industry. Beverage \& Food World, 2013,2, 23-28.

[32] Onwuka, G. I. Soaking, boiling and antinutritional factors in pigeon peas (Cajanus cajan) and cowpeas (Vigna unguiculata). Journal of food processing and preservation, 2006,30(5), 616-630. https://doi.org/10.1111/j.1745-4549.2006.00092.x

[33] Graig, s. and Helfrich, L. A. Understanding Fish Nutrition, feeds and feeding, Yorktown (Viginia): Viginia Cooporative Extension Service Publications 2002, p420-256.

[34] Jouncey, K. Nutritional Requirements. In: M. C. M. Bevendge and B. J. McAndrew, eds. Tilapia: Biology and Exploitation, Fish and FIsheries Series 25. Amsterdam: Kluwer Academic Publishers, Dordecht, 2000,pp. 327-375 https://doi.org/10.1007/978-94-011-4008-9_9

[35] Craig, S., Helfrich, L. A., Kuhn, D., \& Schwarz, M. H. Understanding fish nutrition, feeds, and feeding, 2017. https://fisheries.tamu.edu/files/2019/01/FST-269.pdf (date of access 14.10.2020).

[36] Halver, J. E. and Hardy, R. W. Fish Nutrition. third eddition ed. New York: Academic press. 2002

[37] Gonzalez, C. and Allan, G. Preparing farm-made fish feed, Australia: NSW Department of Primary Industries, 2007.

[38] Hillocks, R. J., Minja, E., Mwaga, A., Nahdy, M. S., \& Subrahmanyam, P. Diseases and pests of pigeon pea in eastern Africa: a review. International Journal of Pest Management, 2000,46(1), 7-18. https://doi.org/10.1080/096708700227534

[39] Smýkal, P., Coyne, C. J., Ambrose, M. J., Maxted, N., Schaefer, H., Blair, M. W., Berger, J., Greene, S.L., Nelson, M.N., Besharat, N \& Vymyslický, T. Legume crops phylogeny and genetic diversity for science and breeding. Critical Reviews in Plant Sciences, 2015, 34(1-3), 43-104. https://doi.org/10.1080/07352689.2014.897904

[40] Damaris, A. O. The potential of pigeon pea (Cajanus cajan (L.) Millsp.) in Africa. In Natural Resources Forum 2007,Vol. 31, No. 80, pp. 297-305). https://doi.org/10.1111/j.1477-8947.2007.00157.x

[41] Shiferaw, B., Silim, S., Muricho, G., Audi, P., Mligo, J., Lyimo, S.,You, L \& Christiansen, J. L. Assessment of the adoption and impact of improved pigeon pea varieties in Tanzania. Journal of SAT Agricultural Research, (2007, 5(1), 1-27.

[42] Emefiene, M. E., Joshua, V. I., Nwadike, C., Yaroson, A. Y., \& Zwalnan, N. D. E. Profitability analysis of Pigeon pea (Cajanus cajan) production in Riyom LGA of Plateau State. International Letters of Natural Sciences, 2014,13(2) https://doi.org/10.5901/ajis.2014.v3n7p44

[43] Tabot, P. T., Fonge, B. A., \& Bechem, E. Simulation of the impacts of three management regimes on carbon sinks in rubber and oil palm plantation ecosystems of South-Western Cameroon. Journal of Ecology and the Natural Environment, 2012, 4(6), 154-162. https://doi.org/10.5897/JENE11.146

[44] Okah, U., Ibeawuch, I. A., \& Herbert, U. Nutrient intake and digestibility by West African Dwarf (WAD) sheep fed graded levels of pigeon pea seed meal. Iranian Journal of Applied Animal Science, 2013,3(2), 263-268.
[45] Cook BG, Pengelly BC, Brown SD, Donnelly JL, Eagles DA, Franco MA, Hanson J, Mullen BF, Partridge IJ, Peters M, Schultze-Kraft R. Tropical Forages: an interactive selection tool. Tropical Forages: an interactive selection tool..2005.

[46] Mallikarjuna, N., Saxena, K. B. and Jadhav, D. R.,. Cajanus cajan. C. Kole (ed.), Wild Crop Relatives: Genomic and Breeding Resources, Legume Crops and Forages.. Andhra Pradesh, India, International Crops Research Institute for Semi Arid Tropics, Patancheru 502324,. 2011

[47] Valenzuela, H. D. and Smith, J.,. CTAHR Sustainable Agriculture Green Manure Crops Series: pigeonpea, s.1.: Univ. Hawaii. Coop. Ext. Serv. SA-GM-8. 2002

[48] Amarteifio, J. O., Munthali, D. C., Karikari, S. K., \& Morake, T. K. The composition of pigeon peas (Cajanus cajan (L. Millsp.) grown in Botswana. Plant Foods for Human Nutrition, 2002,57(2), 173-177. https://doi.org/10.1023/A:1015248326920

[49] Eltayeb, A. R. S. M., Ali, A. O., \& Haron, R. The chemical composition of pigeon pea (Cajanus cajana) seed and functional properties of protein isolate. Pakistan Journal of Nutrition, 2010, 9(11), 1069-1073. https://doi.org/10.3923/pjn.2010.1069.1073

[50] Balogun, B. I. Comparative evaluation of nutritive value of pigeon pea (Cajanus cajan (L.) Willsp.) and cowpea (Vigna Unguiculala (L.) Walp). $J$ VocaTech Edu, 2013,10, 109-121.

[51] Hammed, A. M., Fashina-Bombata, H. A., Adedeji, F. A., \& Kareem, A. L. Effects of partial and total replacement of soyabean meal with pigeon pea (Cajanus cajan) as alternative plant protein source in the diet of juvenile African mud catfish (Clarias gariepinus). The Journal of Food Technolgy. Photo, 2012,105, pp. $139-145$.

[52] Alegbeleye, W. O., Obasa, S. O., Olude, O. O., Moronkeji, T., \& Abdulraheem, I. Growth performance and nutrient utilization of African mud catfish (Clarias gariepinus) fingerlings fed different levels of fermented pigeon pea (Cajanus cajan) meal. Israeli Journal of Aquaculture, 2012,64: 731-739.

[53] Ganzon-Naret, E. S. Evaluation of graded levels of cooked pigeon pea seed meal (Cajanus cajan) on the performance and carcass composition of Asian sea bass (Lates calcarifer). Animal Biology \& Animal Husbandry, 2014,6(1), 1-9.

[54] Ndau, J. L., \& Madalla, A. N. Effects of soaked pigeon peas on the growth of Nile tilapia (Oreochromis niloticus L) fingerlings. Journal of Fisheries \& Livestock Production, 2015. https://doi.org/10.4172/2332-2608.1000125

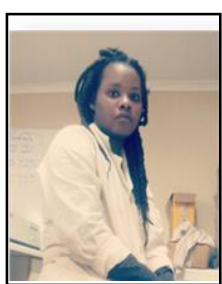

Ralinala Khakhathi Milicent graduated from African Collage of Learning with a Diploma on Office Computer in 2010. She joined the University of Venda in 2011 as an animal science student. She graduated BSC in Agriculture specializing in animal science in 2015. She is currently registered as master's student in Jilin Agricultural University, China. She has worked as an intern at agricultural research council: germplasm conservation and reproductive biotechnologies in 2018.

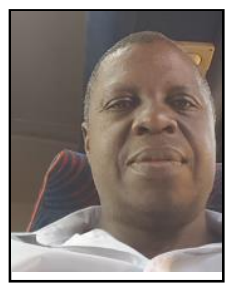

Dr F. Fushai (BSc Agriculture, Animal Science, University of Zimbabwe, 1990; MSc Agriculture, Animal Science, University of Kwazulu-Natal, 1996; $\mathrm{PhD}$, Animal Nutrition, University of South Africa, 2014) is an Animal Nutritionist, with research interest and expertise in climate-smart adaptive feeds and livestock feeding strategies.

He is currently a Senior Lecturer and Researcher in Animal Nutrition in the Department of Animal Science at the School of Agriculture, University of Venda, South Africa. He has substantial previous experience in Agricultural Extension as a Livestock and Range Animal Management Specialist in the Department of Agricultural, Technical \& Extension in Zimbabwe. He is widely published in accredited Animal Nutrition Journals and International Conferences. 


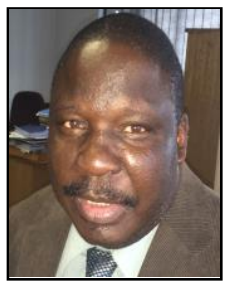

Prof JJ Baloyi graduated with an MSc in Animal Nutrition fron University of Aberdeen (UK) in 1990 and a $\mathrm{PhD}$ in Animal Nnutrition at the University of Zimbabwe in 2002. He worked as a Research officer in both ruminat and aquaclture in Zimbabwe before joining the academia at Agricultural colleges (Chibero and Fort Cox ) and universities (Zimbabwe Open Universy, North West University, University of South Africa and University of Venda). He was appointed as a Senior lecturer in Animal science departmnet at Unversity of Venda in 2009 and promoted to Associate professor in 2016. He has published a number of scientific manuscripts (33) in referred journals and presented many conference papers (45) at both national and international conferences. He has also succesfully supervised $2 \mathrm{PhD}, 16 \mathrm{MSc}$ and 20 Honours students in Animal Science. Prof Baloyi is a member of South African Socoiety of Animal Science (SASAS) and Grassland Society of southern Africa (GSSA). He has also acted as both an external examiner for various universities in and outside Soputh Africa and reviewed a number of manuscripts for publivations in peer reviewed accredited journals. Prof Baloyi was previously awarded awards to study for MSc and short cours in Statistics in the UK, research awards at the University of Venda and lately the Fulbright Research Fellowship to conduct some research at the University of Wyoming in the USA in 2021. Currently Prof Baloyi is the Head of Department of Animal science and the Deputy Dean of the School of Agriculture at the University of Venda.

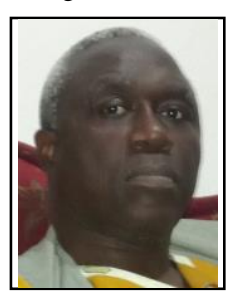

Prof Jabulani Ray Gumbo graduated with a $\mathrm{PhD}$ in

Water Resources Management from University of Pretoria in 2007. He was awarded the second-best student poster price at the 12th International Conference on Harmful Algae in 2006 and the study was then published in the prestigious conference proceedings after a rigorous peer review process. This author became a Member (M) of International Society for the Study of Harmful Algae; International Mine Water Association; Water Institute of Southern Africa; Microscopy Society of Southern Africa and South African Council for Natural Scientific Professions. In 2008, he was appointed as a senior lecturer at University of Venda and in 2016 he was appointed as Associate Professor. He is the first or second author of more than 86 research outputs (3 patents, 38 peer reviewed papers with more than thirds of these published in international journals with an impact factor; 41 peer reviewed conference proceedings and 3 technical reports and four book chapters). He acts as a reviewer for NRF in the fields of cyanobacteria and has been invited to be a reviewer for Ohio Sea Grant Proposal (USA); Journal of Applied Phycology (Australia); Bioresource Technology Journal (BITE) (USA); Journal of Freshwater Ecology (Britain); South African Journal of Science (SAJS) (South Africa) and African Journal of Biotechnology (AJB) (Nigeria). He lectures students at undergraduate and postgraduate levels in the fields of water treatment; water quality management; water law and institutions; rural water supply and sanitation; data information systems and water quality principles and he supervises several Honours, Masters and $\mathrm{PhD}$ students in the fields of water quality management; aquatic ecotoxicology and limnology and water treatment. 